慶應義塾大学学術情報リポジトリ

Keio Associated Repository of Academic resouces

\begin{tabular}{|c|l|}
\hline Title & Anticomplementary and hypoglycemic activity of okra and hibiscus mucilages \\
\hline Sub Title & \\
\hline Author & $\begin{array}{l}\text { 友田, 正司(Tomoda, Masashi) } \\
\text { 清水, 訓(Shimizu, Noriko) } \\
\text { 権田, 良子(Gonda, Ryoko) } \\
\text { 金成, 美枝子(Kanari, Mieko) } \\
\text { 山田, 陽城(Yamada, Haruki) } \\
\text { ヒキノ, ヒロシ(Hikino, Hiroshi) }\end{array}$ \\
\hline Publisher & 共立薬科大学 \\
\hline Publication year & 1989 \\
\hline Jtitle & 共立薬科大学研究年報 (The annual report of the Kyoritsu College of \\
& Pharmacy). No.34 (1989. ),p.58-58 \\
\hline JaLC DOI & \\
\hline Abstract & \\
\hline Notes & 抄録 \\
\hline Genre & Technical Report \\
\hline URL & https://koara.lib.keio.ac.jp/xoonips/modules/xoonips/detail.php?koara_id=AN00062898-0000003 \\
\hline & $4-0058$ \\
\hline
\end{tabular}

慶應義塾大学学術情報リポジトリ(KOARA)に掲載されているコンテンツの著作権は、それぞれの著作者、学会または出版社/発行者に帰属し、その権利は著作権法によって 保護されています。引用にあたっては、著作権法を遵守してご利用ください。

The copyrights of content available on the KeiO Associated Repository of Academic resources (KOARA) belong to the respective authors, academic societies, or publishers/issuers, and these rights are protected by the Japanese Copyright Act. When quoting the content, please follow the Japanese copyright act. 
No. 34 (1989)

\title{
Anticomplementary and Hypoglycemic Activity of Okra and Hibiscus Mucilages*
}

\author{
Masashi Tomoda, Noriko Shimizu, Ryőko Gonda, Mieko Kanari, \\ Haruki YAMADA** and Hiroshi HikIno*** \\ 友田正司, 清水訓子, 権田良子, 金成美枝子, 山田陽城**, \\ ヒキノヒロシ***
}

The present paper describes the anticomplementary activity and hypoglycemic activity of the six mucilages obtained from Abelmoschus esculentus (i.e. Hibiscus esculentus L.; okra), Hibiscus moscheutos and Hibiscus syriacus. Okra-mucilages F and R were isolated from the immature fruit and the root of Abelmoschus esculentus, respectively. Hibiscus-mucilages Mo and ML were isolated from the root and the leaf of Hibiscus moscheutos, and Hibiscus-mucilages SL and SF from the leaf and the flower bud of Hibiscus syriacus, respectively.

Hibiscus-mucilages ML and SF showed remarkable anticomplementary activities. Okra-mucilage $\mathrm{R}$ and Hibiscus-mucilage $\mathrm{SL}$ also had potent activities, which were almost at the same level as that of the positive control, AR-arabinogalactan from the root of Angelica acutiloba. The remarkable activities of these mucilages may result from the highly branched structure. The activities of Okra-mucilage F and Hibiscusmucilage Mo were lower than those of the former four mucilages.

Most of Okra-mucilages F and R and of Hibiscus-mucilages Mo, ML, SL and SF exhibited significant hypoglycemic activity, though the effect of Hibiscus-mucilage ML was dose dependent. These mucilages which showed extensive hypoglycemic activity have a backbone chain consisting of almost only the repeating unit L-rhamno-Dgalacturonan. Okra-mucilage $\mathrm{R}$ especially showed a remarkable activity. It possesses the trisaccharide repeating unit, $(1 \rightarrow 4)-[\beta-\mathrm{D}-\mathrm{Glc} p \mathrm{~A}-(1 \rightarrow 3)]-\alpha-\mathrm{D}-\mathrm{Gal} p \mathrm{~A}-(1 \rightarrow 2)-\alpha-\mathrm{L}-$ Rha $p$, as the main part of the backbone. In addition, it has side chains composed mainly of $\beta$-1,4-linked D-galactopyranose residues, and $\alpha$-1,2-linked L-rhamnopyranosyl residues in part of the backbone. The D-glucuronic acid side-chain groups at $O-3$ of the D-galacturonic acid residues in the backbone are not essential for the hypoglycemic effect, as Okra-mucilage $\mathrm{F}$ showed a significantly activity.

\footnotetext{
* 本報告は Carbohydr. Res., 190,323-328（1989）に発表。

** 北里研究所東洋医学総研

*** 東北大学楽学部
} 